\title{
Meningkatkan Hasil Belajar Matematika Matriks Melalui Pembelajaran Model STAD
}

\author{
Rochani
}

\author{
SMKN 3 Blitar
}

\section{Tersedia Online di \\ http://www.jurnal.unublitar.ac.id/ index.php/briliant}

\section{Sejarah Artikel}

Diterima pada 8 April 2017

Disetuji pada 8 April 2017

Dipublikasikan pada 1 Mei 2017

Hal. 231-238

\section{Kata Kunci:}

matematika, matriks, stad

\begin{abstract}
Abstrak: Penelitian ini bertujuan untuk menganalisis dan merefleksi penerapan model STAD ini. Untuk kemudian dampak apa yang timbulkan dari sisi hasil belajar siswa. Penelitian ini menggunakan rancangan Penelitian Tindakan Kelas (PTK) dengan langkah pelaksanaan siklus, dimana dalam satu siklus terdiri dari perencanaan, pelaksanaan, observasi, dan refleksi. Penelitian ini dilaksanakan dalam tiga siklus. Dengan instrument berupa tes, lembar observasi dan angket. Adapun subyek penelitian ini adalah siswa SMKN 3 Blitar Kelas X jurusan Akomodasi Perhotelan. Setalah dilakukan analisis dapat disimpulkan bahwa Penerapan pembelajaran dengan model STAD dapat meningaktkan Hasil Belajar yang ditandai dengan peningkatan ketuntasan belajar siswa setiap siklus,
\end{abstract}

Hasil ulangan harian matematika yang pertama pada kompetensi dasar matriks tercapai rerata 57,8 dan hanya 50\% siswa mencapai nilai 60 atau $>60$. Padahal idealnya minimal harus mencapai $100 \%$ siswa mendapat 60 atau $>60$. Kondisi tersebut disebabkan oleh kenyataan sehari-hari yang menunjukkan bahwa siswa kelihatannya jenuh mengikuti pelajaran matematika. Pembelajaran seharihari menggunakan metode ceramah dan latihan-latihan soal secara individual, dan tidak ada interaksi antar siswa yang pandai, sedang, dan normal. Hal ini terbukti sebagian besar siswa mengeluh apabila diajak belajar matematika. Seringkali, jika siswa diberi tugas tidak selesai tepat waktu, dan lebih suka mengobrol. Alasannya pelajaran matematika memusingkan dan lain-lain.

Menyikapi kondisi tersebut penulis sebagai guru kelas X selalu berusaha memperbaiki pembelajaran dengan mengkondisikan pembelajaran yang memudahkan, mengasyikkan, dan menyenangkan bagi siswa. Usaha tersebut akan diwujudkan dalam suatu penelitian tindakan kelas yang akan menerapkan pembelajaran Model STAD dan bermain tanya jawab.

Model pembelajaran STAD (Student Team Achievement Devision) adalah salah satu pembelajaran kooperatif yang dikembangkan berdasarkan teori belajar Kognitif-Konstruktivis yang diyakini oleh pencetusnya Vygotsky memiliki keunggulan yaitu fungsi mental yang lebih tinggi akan muncul dalam percakapan atau kerjasama antar individu (Depag RI, 2004).

Adapun Langkah-langkah pembelajaran kooperatif Student Teams Achievment Division (STAD) adalah (1) Menyampaikan kompetensi yang diharapkan dan memotivasi siswa, (2) Menyajikan informasi, (3) Mengorganisasikan siswa ke dalam kelompok bekerja dan belajar, (4) 
Membimbing kelompok bekerja dan belajar, (5) Evaluasi, (6) Memberikan penghargaan.

Pengertian bertanya adalah ucapan verbal yang meminta respons dari seseorang yang dikenai. Respons yang diberikan dapat berupa pengetahuan sampai dengan hal-hal yang merupakan hasil pertimbangan. Jadi bertanya merupakan stimulus efektif yang mendorong berfikir (Hasibuan dan Moejiono, 2004).

Dari pendapat dan pengertian tersebut, bertanya menunjukkan bahwa, baik yang bertanya maupun yang menjawab telah terjadi proses berfikir dari dirinya. Sedangkan berfikir merupakan proses belajar. Pemecahannya adalah mengajukan pertanyaan tentang semua informasi penting.

Di samping itu, pertanyaan-pertanyaan tentang fakta yang disampaikan dengan kata-kata sendiri, bukannya mengulang tepat seperti yang tertulis, membantu siswa mempelajari makna teks itu dan bukannya sekedar menghafalkannya (Mohamad Nur,1998). Pendapat ini mendukung bahwa memberi kesempatan kepada siswa untuk membuat pertanyaan-pertanyaan dan menjawab pertanyaan dari teman adalah sama dengan memberi kesempatan belajar kepada siswa, sehingga pembelajaran berpusat pada siswa atau student center.

Model STAD juga memiliki keunggulan bahwa siswa yang dikelompokkan secara heterogen berdasarkan kemampuan siswa terhadap matematika akan terjadi interaksi yang positif dalam menyelesaikan masalah, seperti tutor sebaya dan lain-lain. Jika sebelumnya tidak ada interaksi antar individu, maka dalam Model STAD siswa dapat bekerja sama dalam menyelesaikan masalah sampai semua anggota kelompok dapat menyelesaikan masalah. Kelompok dikatakan tidak selesai jika ada anggotanya belum selesai.

Melihat hal tersebut maka model STAD dapat memberikan suatu solusi dalam permasalahan yang terjadi saat ini. Sehingga prestasi belajar siswa dapat meningkat sesuai dengan kriteria ketuntasan minimal. Untuk itu asumsi-asumsi tersebut perlu dibuktikan melalui penelitian dengan rumusan menganalisis dan merefleksi penerapan model STAD ini. Untuk kemudian dampak apa yang timbulkan dari sisi hasil belajar siswa.

\section{METODE}

Penelitian ini menggunakan rancangan Penelitian Tindakan Kelas (PTK) dengan tujuan untuk memperbaiki kinerjanya sebagai guru, sehingga hasil belajar siswa menjadi meningkat (Wardani, 2005). Penelitian Tindakan Kelas ini juga sudah bersiklus, yang terdiri dari perencanaan, pelaksanaan, observasi, dan refleksi yang dilakukan secara berulang sebagaimana dinyatakan oleh Kemmis dan Mc Taggart (dalam Yatim Riyanto, 2001).

Penelitian tindakan kelas ini menerapkan model pembelajaran kooperatif STAD (Student Team Achievement Devisions) dengan variasi bermain tanya jawab. Pembelajaran dengan model kooperatif STAD memiliki keunggulan yang dapat mengatasi masalah yang ada. Karena dalam model kooperatif STAD akan terjadi meningkatnya fungsi mental melalui percakapan dan interaksi lainnya, serta kerjasama antar siswa yang memiliki kemampuan yang heterogen.

232 BRILIANT: Jurnal Riset dan Konseptual Volume 2 Nomor 2, Mei 2017 


\section{Lokasi Penelitian}

Penelitian tindakan kelas ini akan dilaksanakan di SMKN 3 Kota Blitar, yang terletak di Jalan S. Supriyadi Kota Blitar. Lebih tepatnya kepada siswa-siswi kelas X Jurusan Akomodasi Perhotelan.

\section{Subyek Penelitian}

Subyek penelitian ini adalah siswa kelas X Akomodasi Perhotelan 4 Tahun Pelajaran 2014/2015 yang berada di SMKN 3 Blitar. Jumlah subyek penelitian 31 siswa yang terdiri dari 3 laki laki dan 28 perempuan. Kondisi kemampuan matematika sangat kurang karena hasil ulangan harian pada pembelajaran sebelumnya hanya mencapai rata-rata 57,8 .

Siswa kelas X Akomodasi Perhotelan 4 sebagai subyek penelitian ini memiliki karakteristik yang heterogen. Heterogen baik dalam segi kemampuan intelegensi, motivasi belajar, latar belakang keluarga, maupun sifat dan wataknya.Dari segi watak ada beberapa siswa yang memiliki watak sulit diatur, sehingga kadang-kadang menyulitkan guru pada saat pembelajaran berlangsung. Namun secara umum memiliki kepribaduan yang cukup baik.

Dilihat dari kemampuan matematika sangat kurang. Permasalahan tersebut mungkin dikarenakan semangat belajar yang kurang. Keadaan tersebut dapat dilihat keadaan sehari-hari, di mana siswa sering mengeluh pusing dan bosan bila diajak belajar matematika. Permasalahan inilah yang mendorong peneliti mengangkat mata pelajaran matematika kompetensi dasar tentang Matriks sebagai obyek penelitian.

\section{Instrumen}

Instrumen yang digunakan dalam penelitian ini adalah tes, lembar observasi, dan angket. Tes digunakan untuk mengumpulkan data hasil belajar. Lembar observasi digunakan untuk mengamati kegiatan pembelajarn kelompok. Angket untuk mengumpulkan data kegiatan pembelajaran tanya jawab, baik penjawab, penanya maupun pengamat.

\section{Teknik Analisis Data}

analisis data dilakukan untuk menganalisis data di atas seperti tes hasil belajar, hasil angket dalam berbagai kegiatan pembelajaran tersebut. Data hasil belajar dianalisis berdasarkan pada ketuntasan belajar, yaitu $100 \%$ siswa mencapai 60 - >60. Data aktifitas pembelajaran klasikal diharapkan dapat mencapai nilai rerata $60 \%$ s.d $70 \%$. Data aktifitas pembelajaran kelompok ditargetkan dapat mencapai rerata 70 s.d. $80 \%$. Data aktifitas pada pembelajaran tanya jawabdiharapkan tiap siswa mampu melaksanakan lima aktifitas dengan benar yaitu: penampilan bertanya, menilai jawaban, membuat kunci jawaban, penampilan menjawab, dan kualitas jawaban. Namun target minimal dapat mencapai rerata sampai $70 \%-80 \%$.

\section{HASIL}

\section{Hasil Penelitian Siklus I}

Pelaksanaan tindakan diawali dengan pembelajaran klasikal, di mana peneliti/Guru membuka pembelajaran dengan berdoa dan menjelaskan bahwa 
pada hari ini kita belajar matematika ditemani oleh Bpk Tekat Budiono sebagai observer, Waktu yang disediakan untuk kegiatan klasikal yaitu 40 menit tepat selesai.

\section{Aktivitas Pembelajaran Pertemuan I}

Data kegiatan tanya jawabkelompok penanya pada tabel tersebut mencapai rerata $85,17 \%$. Tercapainya rerata $85,17 \%$ pada kegiatan tanya jawabmelalui observasi kelompok penanya telah mencapai jauh di atas yang diharapkan yaitu 60-70\%. Sedangkan hasil observasi kegiatan penjawab dapat dilaporkan pada lampiran.

Tercapainya rerata $64,47 \%$ pada kegiatan tanya jawabmelalui observasi kelompok penjawab telah mencapai target yang diharapkan yaitu 60-70\%. Apabila diambil rerata dari kelompok penanya dan penjawab dapat dilihat sebagai berikut: $(85,17 \%+64,47 \%): 2=74,82 \%$. Maka dapat diambil kesimpulan sementara bahwa proses pembelajaran melalui kegiatan tanya jawabtelah mencapai target yang telah ditentukan, bahkan mencapai di atas target yang diharapkan.

Data kegiatan tanya jawabkelompok penanya pada tabel tersebut mencapai rerata $85,17 \%$. Tercapainya rerata $85,17 \%$ pada kegiatan tanya jawabmelalui observasi kelompok penanya telah mencapai jauh di atas yang diharapkan yaitu 60-70\%. Sedangkan hasil observasi kegiatan penjawab dapat dilaporkan pada lampiran.

Tercapainya rerata $64,47 \%$ pada kegiatan tanya jawabmelalui observasi kelompok penjawab telah mencapai target yang diharapkan yaitu 60-70\%. Apabila diambil rerata dari kelompok penanya dan penjawab dapat dilihat sebagai berikut $(85,17 \%+64,47 \%): 2=74,82 \%$. Maka dapat diambil kesimpulan sementara bahwa proses pembelajaran melalui kegiatan tanya jawabtelah mencapai target yang telah ditentukan, bahkan mencapai di atas target yang diharapkan.

\section{Aktivitas Pembelajaran Pertemuan II}

Data menunjukkan nilai yang sangat tinggi yaitu nilai rerata $91,66 \%$, jauh di atas yang diharapkan yaitu 70-80 \%. Pada kegaiatan kelompok ini memang hampir semua siswa aktif melakukan kegiatan belajar sesuai tugasnya masing-masing. Kemudian dilanjutkan dengan kegiatan tanya jawab atau bertanya menjawab.

\section{Hasil Belajar Pertemuan I}

Hasil belajar jumlah siswa yang hadir 24 siswa. 16 siswa telah mencapai ketuntasan belajar atau 66,66\% telah mencapai nilai 60 - >60. Masih ada 8 siswa yang belum mencapai ketuntasan belajar atau 33,33\% masih mendapat nilai $<60$. Maka target hasil belajar pada siklus I belum dapat tercapai. Walaupun ada kenaikan rerata dari kondisi semula yaitu dari 57,80 dan hanya 50\% siswa yang mencapai ketuntasan belajar. Oleh karena itu perlu adanya perbaikan-perbaikan pada siklus berikutnya sesuai dengan masukan-masukan baik dari pengamat maupun dari peneliti sendiri. Ditinjau dari jumlah kesalahan siswa pada soal 
nomor 1 dan 4 lebih dari separoh siswa yaitu 17/18 siswa masih mengalami kesalahan. Maka perlu penjelasan ulang tentang penyelesaian soal nomor 1 dan 4 tersebut. Penjelasan ulang itu dilakukan pada waktu sebelum melanjutkan pertemuan II siklus I. Sedangkan siswa-siswa yang belum tuntas diberi bimbingan di luar jam efektif dan diberi tugas latihan soal-soal untuk dikerjakan di rumah.

\section{Hasil Belajar Pertemuan II}

Jumlah siswa yang hadir 24 siswa. 16 siswa telah mencapai ketuntasan belajar atau 66,66\% telah mencapai nilai $60->60$. Masih ada 8 siswa yang belum mencapai ketuntasan belajar atau 33,33\% masih mendapat nilai < 60. Maka target hasil belajar pada siklus I belum dapat tercapai. Walaupun ada kenaikan rerata dari kondisi semula yaitu dari 57,80 dan hanya 50\% siswa yang mencapai ketuntasan belajar. Oleh karena itu perlu adanya perbaikan-perbaikan pada siklus berikutnya sesuai dengan masukan-masukan baik dari pengamat maupun dari peneliti sendiri. Ditinjau dari jumlah kesalahan siswa pada soal nomor 1 dan 4 lebih dari separoh siswa yaitu 17/18 siswa masih mengalami kesalahan. Maka perlu penjelasan ulang tentang penyelesaian soal nomor 1 dan 4 tersebut. Penjelasan ulang itu dilakukan pada waktu sebelum melanjutkan siklus II. Sedangkan siswa-siswa yang belum tuntas diberi bimbingan di luar jam efektif dan diberi tugas latihan soal-soal untuk dikerjakan di rumah.

\section{Hasil Penelitian Siklus II Pertemuan I}

Pelaksanaan tindakan diawali dengan pembelajaran klasikal, di mana peneliti/Guru membuka pembelajaran dengan berdoa dan menjelaskan bahwa pada hari ini kita belajar matematika ditemani oleh Bpk Tekat Budiono dan Ibu Komsijah sebagai observer. Waktu yang disediakan untuk kegiatan klasikal yaitu 40 menit tepat selesai.

Siswa yang mencapai ketuntasan belajar mencapai 76,92\%. Walaupun belum mencapai target yang ditentukan yaitu $100 \%$ siswa tuntas, namun terdapat kenaikan ketuntasan belajar dibandingkan dengan siklus I yang baru mencapai $66,66 \%$. Dengan demikian masih ada 23,08\% atau 6 siswa yang belum tuntas. Untuk itu diperlukan remidial melalui bimbingan belajar bagi keenam siswa tersebut. Dilihat dari materi soal nomor 9 dan 10, masih $>50 \%$ siswa belum berhasil menyelesaikan dengan benar. Maka diperlukan penjelasan ulang atau remidial klasikal tentang soal nomor 9 dan 10 .

\section{Pertemuan II}

Siswa yang mencapai ketuntasan belajar mencapai 76,92\%. Walaupun belum mencapai target yang ditentukan yaitu $100 \%$ siswa tuntas, namun terdapat kenaikan ketuntasan belajar dibandingkan dengan pertemua I siklus II yang baru mencapai 66,66\%. Dengan demikian masih ada 23,08\% atau 6 siswa yang belum tuntas. Untuk itu diperlukan remidial melalui bimbingan belajar bagi keenam siswa tersebut. Dilihat dari materi soal nomor 9 dan 10, masih $>50 \%$ siswa belum berhasil menyelesaikan dengan benar. Maka diperlukan penjelasan ulang atau remidial klasikal tentang soal nomor 9 dan 10 . 


\section{Hasil Penelitian Siklus III Aktivitas Siswa}

Angka rerata dari belajar kelompok sebesar 97,91\%. Sedangkan pada siklus II belajar kelompok telah menunjukkan rerata 92,85\%. Maka terdapat peningkatan 5,06\% dari siklus II. Peningkatan kegiatan kelompok ini disebabkan karena hampir semua kelompok mencapai keaktifan 100\% kecuali kelompok A dan F karena masing-masing kelompok tersebut ada satu siswa yang kurang berpendapat dalam diskusi kelompok. Hasil observasi tersebut telah mencapai jauh di atas target yang ditentukan.

\section{Hasil Belajar}

Hasil belajar siswa yang mencapai rerata 79,61\% dengan ketuntasan belajar $100 \%$. Dengan demikian indikator keberhasilan telah dicapai yaitu $100 \%$ siswa mengalami ketuntasan belajar. Namun demikian masih ada dua soal yaitu soal nomor 7 dan nomor 9 masih ada 15 siswa yang belum bisa menyelesaikan dengan benar. Karena ada $>50 \%$ siswa yang belum menguasai maka perlu ditindaklanjuti dengan penjelasan ulang secara klasikal.

\section{PEMBAHASAN}

\section{Pelaksanaan Pembelajaran Model STAD}

Dalam rangka meningkatkan hasil belajar harus melalui peningkatan proses pembelajaran. Peningkatan proses pembelajaran dilakukan melalui tindakan kelas dan saat ini lebih dikenal dengan penelitian tindakan kelas. Penelitian tindakan kelas merupakan suatu pencermatan terhadap kegiatan belajar berupa sebuah tindakan, yang sengaja dimunculkan dan terjadi dalam sebuah kelas secara bersama. Tindakan tersebut diberikan oleh guru atau dengan arahan dari guru yang dilakukan oleh siswa .

Setiap guru tidak pernah lepas dari permasalahan pembelajaran di kelasnya. Untuk mengatasinya diperlukan ide-ide untuk mengatasinya. Namun dalam menentukan suatu strategi pembelajaran guru perlu ingat pendapat yang mengatakan bahwa, seseorang mampu mengingat $90 \%$ dari apa yang ia lakukan . Jadi dalam menyusun strategi pembelajaran guru harus berfikir apakah yang harus siswa lakukan agar mereka dapat menguasai kompetensi dasar yang dikehendaki.

Penelitian di kelas X Akomodasi Perhotelan SMKN 3 Blitar, yaitu siswa tidak bersemangat dalam mengikuti pembelajaran Matematika dan berakibat hasil belajar tidak mencapai ketuntasan belajar. Kondisi awal hasil belajar yang dicapai hanya 50\% siswa yang tuntas mencapai nilai 60 - >60 dengan rerata 57,8. Setelah dilakukan tindakan oleh guru yang dilakukan oleh siswa berupa belajar klasikal dan kelompok model kooperatif STAD yang dilakukan melalui tiga siklus dan hasil pengamatan menunjukkan peningkatan dari siklus ke siklus.

Data hasil pengamatan pembelajaran klasikal dari siklus I mencapai $54,22 \%$, siklus II mencapai $66,15 \%$, dan siklus III mencapai $84,61 \%$. Peningkatan tersebut menunjukkan peningkatan semangat belajar siswa dalam mengikuti pembelajaran matematika. Untuk mengetahui gambaran peningkatan proses pembelajaran melalui Kooperatif Model STAD.Hasil pengamatan pembelajaran kooperatif Model STAD dari siklus I mencapai 91,66\%, siklus II mencapai

236 BRILIANT: Jurnal Riset dan Konseptual Volume 2 Nomor 2, Mei 2017 
92,85\%, dan siklus III mencapai 97,91\%. Peningkatan tersebut menunjukkan peningkatan semangat belajar siswa dalam mengikuti pembelajaran matematika. Dari dua gambar tersebut membuktikan bahwa belajar klasikal dan Kooperatif Model STAD dapat meningkatkan proses pembelajaran dan meningkatkan semangat belajar siswa dalam mengikuti pembelajaran Matematika. Maka dari rumusan masalah pertama yang diajukan yaitu: Bagaimana pembelajaran model kooperatif STAD dapat mendorong siswa untuk belajar tentang luas bangun lebih bersemangat ? dapat terjawab dengan data di atas. Sehingga dapat disimpulkan bahwa Pembelajaran dengan Model Kooperatif STAD dapat mendorong siswa untuk belajar matriks lebih bersemangat.

Dengan terjawabnya kedua rumusan masalah yang diajukan maka kedua hipotesis tindakan yang diajukan pun dapat diterima. Sehingga dapat disimpulkan bahwa baik secara teori maupun pengalaman di lapangan belajar melalui Model Kooperatif STAD dapat membantu memecahkan masalah dalam pembelajaran matematika. Masalah pembelajaran tersebut dapat berupa masalah hasil belajar menurun, motivasi maupun semangat belajar yang kurang.

\section{Hasil Belajar}

Peningkatan rerata hasil belajar yang diikuti oleh ketuntasan belajar. Siklus I dicapai rerata 65 dan siswa tuntas belajar 66,66\%, Siklus II dicapai rerata 72,3 dan siswa tuntas belajar 76,92\%, Siklus III dicapai rerata 79,61 dan siswa tuntas belajar $100 \%$, Karena ketuntasan belajar telah mencapai 100\% mendapat nilai 60 - > 60 maka target yang ditentukan telah dicapai.

Peningkatan proses pembelajaran dan hasil belajar dapat ditunjukkan kemajuan-kemajuan yang dicapai dari seluruh kegiatan mulai dari siklus I, siklus II, dan siklus III. Pada pembelajaran klasikal selain mengalami peningkatan dari siklus ke siklus, kenaikan itu sendiri juga mengalami peningkatan yaitu dari 11,93 menjadi 18,46. Begitu juga pada kegiatan kelompok kooperatif Model STAD, dari kenaikan 1,19 menjadi 5,06.

Hasil belajar terjadi kenaikan dari siklus ke siklus dan terjadi peningkatan kemajuan dari kondisi semula ke siklus I adalah 7,2, dari siklus I ke siklus II 7,3 dan dari siklus II ke siklus III 7,31. Peningkatan kenaikan memang sangat tipis, namun karena kompetensi dasar yang harus dicapai juga semakin sulit maka terjadinya kenaikan tersebut juga cukup berarti.

\section{KESIMPULAN}

Dari hasil penelitian yang telah dilakukan tiga siklus, dan berdasarkan pembahasan serta analisis yang telah dilakukan dapat disimpulkan sebagai berikut: (1) Penerapan pembelajaran dengan model STAD pada materi pelajaran mempunyai pengaruh positif, yaitu dapat meningkatkan motivasi belajar siswa yang ditunjukkan dengan rata-rata jawaban siswa yang menyatakan bahwa siswa tertarik dan berminat dengan pembelajaran dengan model STAD pada materi pelajaran sehingga mereka menjadi termotivasi untuk belajar. (2) Hasil Belajar dengan model STAD terjadi peningkatkan prestasi belajar siswa yang ditandai dengan peningkatan ketuntasan belajar siswa setiap siklus, yaitu siklus I $(48,39 \%)$, siklus II $(64,527 \%)$, Siklus III $(93,55 \%)$. 


\section{SARAN}

Untuk peneliti. Untuk melaksanakan pembelajaran dengan model STAD pada materi pelajaran memerlukan persiapan yang cukup matang, sehingga guru harus mampu menentukan atau memilih topik yang benar-benar bisa diterapkan dengan pembelajaran dengan model STAD pada materi pelajaran proses belajar mengajar sehingga diperoleh hasil yang optimal. Untuk siswa. Untuk meningkatkan prestasi belajar siswa, guru hendaknya lebih sering melatih siswa dengan kegiatan penemuan, walau dalam taraf yang sederhana, dimana siswa nantinya dapat menemukan pengetahuan baru, memperoleh konsep dan keterampilan, sehingga siswa berhasil atau mampu memecahkan masalah-masalah yang dihadapinya.

\section{DAFTAR RUJUKAN}

Arikunto,Suharsimi \& Suharjono \& Supardi. 2006, Penelitian Tindakan Kelas. Jakarta: Bumi Aksara.

Departemen Agama RI. 2001. Bahan Penataran ( Modul Metodologi Pendidikan Agama Islam) Jakarta: Direktorat Jendral Pembinaan Kelembagaan Agama Islam.

Departemen Agama RI. 2004. Strategi Pembelajaran Matematika untuk Tingkat Madrasah Aliyah. Jakarta: Badan Litbang Agama dan Diklat Keagamaan Pusdiklat Tenaga Teknis Keagamaan.

Hasibuan \& Mujiono. 2004. Proses Belajar Mengajar. Bandung: Remaja Rosdakarya.

Nur, Mohammad. 1998. Teori Pembelajaran Kognitif. Surabaya: PPS IKIP Surabaya.

Undang-Undang Republik Indonesia Nomor 20 Tahun 2003 tentang Sistem Pendidikan Nasional. 2003. Jakarta: Cemerlang.

Wardani, I.G.A.K. 2005. Penelitian Tindakan Kelas. Jakarta: Universitas terbuka Departemen Pendidikan Nasional.

Riyanto, Yatim. 2001. Metodologi Penelitian Pendidikan. Surabaya: Penerbit SIC.

Yuwono, Trisno \& Abdullah Pius. 1994. Kamus Lengkap Bahasa Indonesia Praktis. Surabaya: Arkola. 